\title{
Bleed Water Testing Program for Controlled Low Strength Material
}

by

C. A. Langton

Westinghouse Savannah River Company

Savannah River Site

Aiken, South Carolina 29808

N. Rajendran

T. M. Nixon

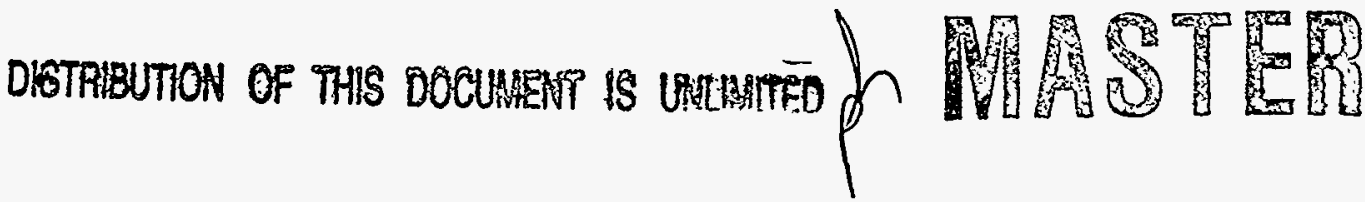

DOE Contract No. DE-AC09-89SR18035 \& DE-AC09-96SR18500

This paper was prepared in connection with work done under the above contract number with the U. S. Department of Energy. By acceptance of this paper, the publisher and/or recipient acknowledges the U. S. Government's right to retain a nonexclusive, royalty-free license in and to any copyright covering this paper, along with the right to reproduce and to authorize others to reproduce all or part of the copyrighted paper. 


\section{DISCLATMER}

This report was prepared as an account of work sponsored by an agency of the United States Government: Neither the United States Government nor any agency thereof, nor any of their employees, makes any warranty, express or implied, or assumes any legal liability or -responsibility for the accuracy, completeness, or usefiliness of any information, apparatus, product, or process disclosed, or represents that its use would not infringe privately owned rights. Reference herein to any specific commercial product, process, or service by trade name, trademark, manufacturer, or otherwise does not necessarily constitute or imply its endorsement. recommendation, or favoring by the United States Government ar any agency thereof. The views and opinions of authors expressed herein do not necessarily state or reflect those of the United States Govemment or any agency thereof.

This report has been reproduced directly from the best available copy.

Available to $D O E$ and $D O E$ contractors from the Office of Scieritific and Technical Information, P.O.Box 62, Oak Ridge, TN 37831; prices available from (615) 57.6-8401.

Available to the public from the. National Technical.Information Service, U.S. Department of Commerce, 5285 Port Royal Road, Springfield, VA 22161. 


\section{DISCLAMIER}

Portions of this dosament may be illegible in electronic image products. Images are produced from the best available original docomeneot 
WSRC-RP-96-554-TL

Key Words: Concrete, Backfill,

Tank 20F.

October 22, 1996

To: R. Palaniswamy, 730-1B

B. T. Butcher, $773-43 \mathrm{~A}$

D. R. Buchanan, 742-2G

From: N. Rajendran, $730-1 \mathrm{~B}$ r of
C. A. Langton, $773-43 \mathrm{~A}$ Cal

T. M. Nixon, $730-1 \mathrm{~B}$

BLEED WATER TESTING PROGRAM FOR CONTROLLED LOW STRENGTH MATERIAL (CLSM) (U).

\section{SUMMARY}

Bleed water measurements for two Controlled Low Strength Material (CLSM) mixes were conducted to provide engineering data for the Tank 20F closure activities CLSM Mix 1 contained 150 pounds of cement per cubic yard whereas CLSM Mix 2 contained 50 pounds per cubic yard. (SRS currently uses CLSM Mix 2 for various applications.) The mix proportions are given in Table 1.

Bleed water percentages and generation rates were measured along with flow and compressive strength. This information will be used to select a mix design for the Tank 20F closure activities and to establish the engineering requirements, such as, lift height, time required between lifts and quantity of bleed water to be removed from the tank during the placement activities.

Mix 1 is recommended for placement with Tank 20F because it has better flow characteristics, less segregation, lower percentage of bleed water and slightly higher strength. Optimization of Mix 1 was beyond the scope of this study. However, further testing of thickening additives, such as clays (bentonite), sodium silicate or fine silicas may be useful for decreasing or eliminating bleed water.

See the attached report WSRC-RP-96-554 for results, discussion and recommendations related to this work. 


\title{
BLEED WATER TESTING PROGRAM FOR CONTROLLED LOW STRENGTH MATERIAL (CLSM)
}

\author{
Prepared By \\ N. Rajendran, BSRI \\ Christine A. Langton, SRTC \\ and \\ Thomas M. Nixon, BSRI
}

Revision: 0
Date: 10/22/96 


\section{Table of Contents}

Page

1.0 SUMMARY

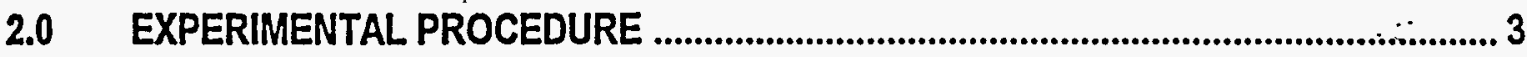

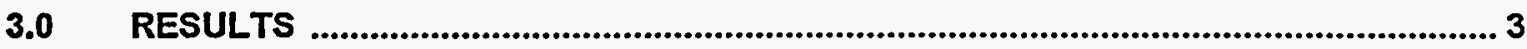

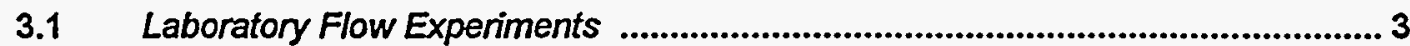

$3.2 \quad 55$ Gallon Drum Flow Experiment ..................................................................... 3

3.3 Bleed Water Laboratory Experiment ............................................................. 4

3.4 55 Gallon Drum Bleed Water Experiment ...................................................... 4

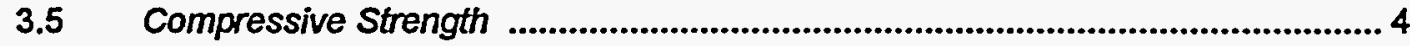

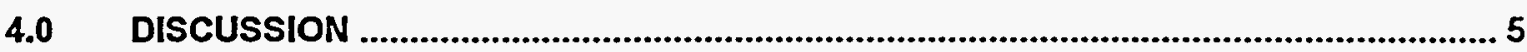

4.1 Compressive Strength, Flow, And Bleed Water Properties ................................ 5

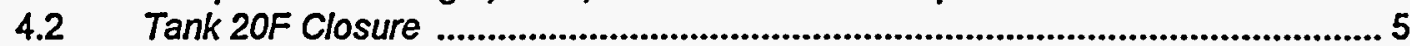

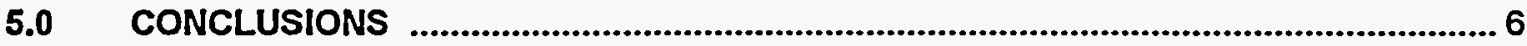

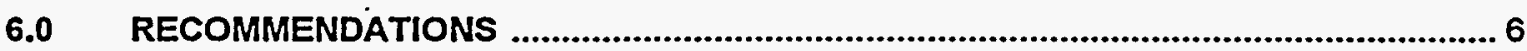

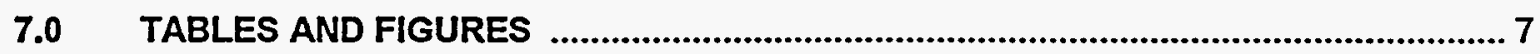

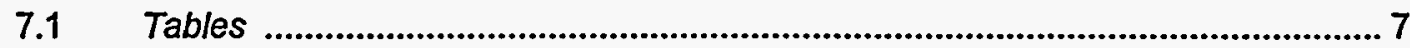

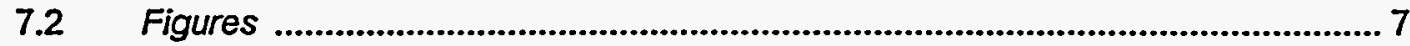

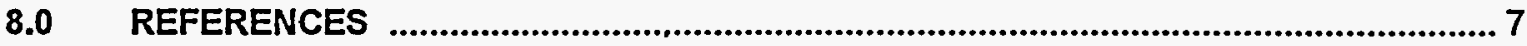

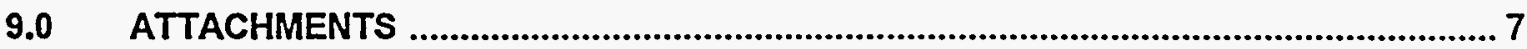




\subsection{SUMMARY}

Bleed water measurements for two Controlled Low Strength Material (CLSM) mixes were conducted to provide engineering data for the Tank 20F closure activities. CLSM Mix 1 contained 150 pounds of cement per cubic yard whereas CLSM Mix 2 contained 50 pounds per cubic yard. (SRS currently uses CLSM Mix 2 for various applications.) The mix proportions are given in Table 1.

Bleed water percentages and generation rates were measured along with flow and compressive strength. This information will be used to select a mix design for the Tank 20F closure activities and to establish the engineering requirements, such as, lift height, time required between lifts and quantity of bleed water to be removed from the tank during the placement activities.

Mix 1 is recommended for placement within Tank 20F because it has better flow characteristics, less segregation, lower percentage of bleed water and slightly higher strength. Optimization of Mix 1 was.beyond the scope of this study. However, further testing of thickening additives, such as clays (bentonite), sodium silicate or fine silicas may be useful for decreasing or eliminating bleed water.

\subsection{EXPERIMENTAL PROCEDURE}

Two mixes were prepared by Raytheon/EBASCO personnel at the concrete testing facility in NArea. The ingredients and proportions of the mixes used are given in Table 1. A three cubic foot paddle mixer was used for the batching of the CLSM mix designs. In addition, 0.25 cubic foot batches were prepared under laboratory conditions to provide better control of the mixing proportions and curing. Preparation of the CLSM mixes was in accordance with ASTM D4832. Flow (evaluated per $\mathrm{ACl} 229$ ) and temperature was measured on each of the batches prepared for the bleed water experiments.

After mixing, the CLSM mixes were poured into one of three 55 gallon drums. Pour heights in the drums were 1, 2, and 3 feet, respectively. The drums were covered after filling to prevent evaporation. Bleed water was measured as a function of elapsed time after pouring. The measurements were made by siphoning the water off and measuring the volume. The water was retumed to the drum after each measurement to monitor changes versus time. The testing was done in accordance with the testing procedures identified in Attachment " $A$ ". Laboratory samples were cast at the Savannah River Technology Center (SRTC) in sealed 12 inch by 4-1/2 inch seethrough plastic cylinder molds. Bleed water was pipetted off of the molds for measurements. The water was returned to the molds after each measurement to monitor changes versus time.

\subsection{RESULTS}

\subsection{Laboratory Flow Experiments}

Flow was evaluated on a small scale. Samples were prepared under laboratory conditions. The flow results for Mix 1 and Mix 2 containing the maximum water content were about 11 and 9-3/4 inches respectively. (See Table 2.)

\subsection{Gallon Drum Flow Experiment}

The CLSM mix designs typically have a range of allowable water content. For this testing, Mix 1 and Mix 2 were evaluated at the minimum (62 gallons per cubic yard) and maximum (66 gallons per cubic yard) water content. The results indicated that CLSM mixes with minimum water content are flowable. According to $\mathrm{ACl} 229$, flowable is defined as a spread diameter of at least 8 inches and no noticeable segregation 
(Reference 1). The flow data are tabulated in Table 2. The spread diameter for Mix 1 with minimum water content ranged from $10-1 / 2$ to 11 inches. The maximum water content showed a range from 11 to 12-1/4 inches. The spread diameter for Mix 2 ranged from $9-3 / 8$ to $10-1 / 2$ inches for the minimum water content and 11 to $11-1 / 4$ inches for the maximum water content. A Slight amount of segregation was observed from Mix 2 but not from Mix 1.

\subsection{Bleed Water Laboratory Experiment}

Bleed water is the migration of water to the top surface of freshly placed CLSM caused by the settlement of the solid materials (cement, sand and fly ash) within the mass. Essentially, the water within the placed CLSM "bleeds" to the surface of the placement. Settlement is a consequence of the combined effect of vibration and gravity or just gravity alone.

Bleed water was measured for Mix 1 and Mix 2 prepared with the maximum water contents under laboratory conditions. After 24 hours of curing, $11.1 \%$ of the initial mixing water segregated as bleed water for Mix 1 and $11.8 \%$ for Mix 2 . After 4 days, a small amount of the bleed water was reabsorbed into Mix 1 (10.5\% bleed water) and Mix $2(11.6 \%$ bleed water). These indications mean that Mix 2 absorbs less bleed water than Mix 1.

\subsection{Gallon Drum Bleed Water Experiment}

Bleed water measurements for Mix 1 with minimum and maximum water content are presented in Tables 4,5 and 6 for heights of 1,2 and 3 foot placements respectively. The results for Mix 2 with a maximum water content and a 3 foot placement are provided in Table 7.

After 24 hours of curing, the percentage of bleed water generated from Mix 1 was $9.89 \%$ (average) with minimum water content and $13.0 \%$ (average) for maximum water content. Some bleed water was reabsorbed for all pour heights evaluated between the initial measurement and the day 4 measurement. After 4 days, the percentage of bleed water did not significantly change. The average values derived from the placements for Mix 1 ( 1,2 and 3 foot placements) ranged from $8.7 \%$ (minimum water content) to $12.1 \%$ (maximum water content). (See Figures 1, 2 and 3.)

After 24 hours for the test performed for Mix 2, 14.2\% bleed water was measured. After 4 days, $13.4 \%$ was measured.

\subsection{Compressive Strength}

The compressive strength results for Mix 1 and Mix 2 are presented in Table 3 and Figures 8 and 9 . The strength was measured after 7 and 28 days of curing. Mix 1 showed higher strength at 7 and 28 days than Mix 2 for both the minimum and maximum water contents.

All mixes tested met the SRS recommended requirements for CLSM of 30 pounds per square inch to 150 pound per square inch after a 28 day curing period. However, Mix 2 with the maximum water content showed an average strength that just met the requirements. 


\subsection{DISCUSSION}

\subsection{Compressive Strength, Flow, And Bleed Water Properties}

The strengths of Mixes 1 and 2 are directly related to the cement and inversely related to the water content. More cement results in higher strengths. Consequently, Mix 1 with 150 pounds of cement per cubic yard has higher strengths at 7 and 28 -days than does Mix 2 (50 pounds of cement per cubic yard). Mix 2 , made with the minimum water content of 62 gallons per cubic yard, has higher strength than the same mix design made with a maximum water content of 66 gallons per cubic yard.

Flow was found to be directly dependent on the cement and water content. Greater flow was achieved by increasing both the cement and water content. Mix 1 had more flow than Mix 2 for equivalent water contents. This trend was observed on both the laboratory and field prepared mixes (55 gallon drums) (See Table 2.). The lower flow measured in the laboratory samples is attributed due to a lower moisture content of the sand.

The equations for predicting flow between the 62 to 66 gallons per cubic yard range are shown in Figure 11 for Mix 1 and Mix 2. For the same amount of water, Mix 1 has 10 percent more flow than Mix 2. Additional water must be added to Mix 2 in order to increase the flow of Mix 2 by 10 percent to make it equivalent to Mix 1 . For batch plant proportioning, the amount of additional water is approximately 5 gallons per cubic yard.

Bleed water will be apparent since the addition of more water will cause segregation. Therefore, adding extra water to Mix 2 to achieve better flow characteristics comparable to that of Mix 1 is not recommended.

The percentage of bleed water is also a function of the amount of mixing water and the amount of cement. Mixes with higher water contents will generate a higher percentage of bleed water. CLSM mixes with higher cement content will generate a lower percentage of bleed water.

Bleed water results were confirmed in the laboratory experiments. The lower percentages of bleed water measured in the laboratory samples is attributed to a slightly lower moisture content of the sand used compared to that used in the experiment with the 55 gallon drums.

\subsection{Tank 20F Closure}

The amount of bleed water is proportional to the water in the design mix and the volume of CLSM poured into Tank 20F. Therefore, the following conversion should be used:

Gallons of Bleed Water $=\%$ Bleed Water (gals of Water ave / cyd of CLSM) * (cyd of CLSM)

For Mix 1 with maximum water, the amount of bleed water expected after 24 hours for a one foot lift is approximately 1800 gallons. If this water is distributed evenly within Tank $20 \mathrm{~F}$, the depth of the bleed water would be about one half inch. Since it is difficult to remove such a small layer, much thicker lifts are needed to be practical for removal (See Section 6.0, Recommendations). 


\subsection{CONCLUSIONS}

Both of the mixes with the minimum (62 gal/cyd) and maximum (66 gal/cyd) water contents were self leveling per the $\mathrm{ACl} 229 \mathrm{CLSM}$ flow test.

Increasing the cement content of CLSM from 50 to 150 pounds per cubic yard increases the flow and the compressive strength of the material and decreases the extent of sand segregation. This results in a more homogeneous mix and also reduces the percentage of bleed water.

The bleed water, as a percent of the total mix water generated in a closed tank, such as Tank 20F, using Mix 1 fill material, is independent of the lift height per CLSM volume. It is, however, dependent on the amount of water in the mix. Mix 1 has an allowable water content of 62 to 66 gallons per cubic yard. After curing for various times, the relationship between the percent bleed water and the amount of water in the original mix are given by the following equations:

$$
\begin{aligned}
& y=0.79 x-38.8 \\
& y=0.87 x-44.4 \\
& y=0.84 x-43.0
\end{aligned}
$$$$
\text { Elapsed Time }=24 \mathrm{Hrs}
$$

where: $x=$ amount of total water in the mix in gallons per cubic yard, $y=$ bleed water as a percent of the total water in the mix.

These equations are valid only when the amount of water in the mix is between 62 and 66 gallons per cubic yard.

The freshly mixed CLSM flow relationship between Mix 1 and Mix 2 is also established for water contents between 62 and 66 gallons per cubic yard. The following equations are then applied:

$$
\begin{array}{lr}
y=0.26 x-5.3 & \text { For Mix 1 } \\
y=0.35 x-12.0 & \text { For Mix 2 }
\end{array}
$$

where: $x=$ amount of water in the mix, gallons per cubic yard, $y=$ flow, inches.

\subsection{RECOMMENDATIONS}

1. Use Mix 1 because of the better flow characteristics, less bleed water and segregation and higher strength.

2. Use as little water as possible to achieve the desired flow. This should be done and supervised by a knowledgeable person familiar with CLSM or an experienced Construction Engineer.

3. Pour 3000 to 3500 cubic yards of Mix 1 before attempting to remove bleed water. This will generate at least six inches of bleed water to make it easier for removal.

4. Optimize Mix 1 to further minimize bleed water. Inorganic slurry thickeners such as clay (bentonite, etc.), sodium silicates or fine silica, in addition to air entraining and superplastizer admixtures, are recommended for future testing.

5. Prior to the start of filling Tank 20F, a trial mix should be made at the batch plant and evaluated at SRS for drop height, segregation, flow, pumpability and the minimum water requirement. If pumpability is questionable, the mix proportions must be adjusted accordingly. 


\subsection{TABLES AND FIGURES}

7.1 Tables:

Table 1

Table 2

Table 3

Table 4

Table 5

Table 6

Table 7

7.2 Figures:

Figure 1

Figure 2

Figure 3

Figure 4

Figure 5

Figure 6

Figure 7

Figure 8

Figure 9

Figure 10

Figure 11
CLSM Mix Proportions For Mix 1 And Mix 2.

Flow Results For Mix 1 And Mix 2.

Compressive Strength Results For Mix 1 And Mix 2.

Mix 1 (150 lbs/cyd) - Bleed Water Volume And Percentage For Minimum And Maximum Water Content - 1 Foot Placement.

Mix 1 (150 lbs/cyd) - Bleed Water Volume And Percentage For Minimum And Maximum Water Content - 2 Foot Placement.

Mix 1 (150 lbs/cyd) - Bleed Water Volume And Percentage For Minimum And Maximum Water Content - 3 Foot Placement.

Mix 2 (50 lbs/cyd) - Bleed Water Volume And Percentage For Maximum Water Content - 3 Foot Placement.

Mix 1 (150 lbs/cyd) - Percentage Of Bleed Water Versus Elapsed Time For Minimum And Maximum Water Content - 1 Foot Placement.

Mix 1 (150 lbs/cyd) - Percentage Of Bleed Water Versus Elapsed Time For Minimum And Maximum Water Content - 2 Foot Placement.

Mix 1 (150 lbs/cyd) - Percentage Of Bleed Water Versus Elapsed Time For Minimum And Maximum Water Content - 3 Foot Placement.

Mix 1 (150 lbs/cyd) - Minimum \& Maximum Water Comparison.

Mix 1 (150 lbs/cyd) - Percentage Bleed Water Placement Comparison (Minimum Water $=62$ gals/cyd).

Mix 1 (150 lbs/cyd) - Percentage Bleed Water Placement Comparison (Maximum Water $=66 \mathrm{gals} / \mathrm{cyd}$ ).

Comparison Of Flow Between Mix 1 And Mix 2.

Mix 1 (150 lbs/cyd) - Compressive Strength Results For Minimum And Maximum Water Content.

Mix 2 (50 lbs/cyd) - Compressive Strength Test Results For Minimum And Maximum Water Content.

Percent Bleed Water Vs Mix 1 - Water Content After 1, 2, And 3 Days.

Flow Vs Water Content.

\subsection{REFERENCES}

1. American Concrete Institute Committee Report ACI 229R-94, Controlled Low Strength Material (CLSM), ACl Manual of Concrete Practice, October 1, 1994.

\subsection{ATTACHMENTS}

Attachment A
Tank 20F Closure

CLSM Bleed Water Test Procedure (U), Revision 1 
Table 1

CLSM Mix Proportions For Mix 1 And Mix 2

\begin{tabular}{|c|c|c|}
\hline Ingredients & Mix 1 & Mix 2 \\
\hline \hline Cement, Type $/ / \mathrm{ll}$ & $150 \mathrm{lbs} / \mathrm{cyd}$ & $50 \mathrm{lbs} / \mathrm{cyd}$ \\
\hline Fly Ash, Type F & $500 \mathrm{lbs} / \mathrm{cyd}$ & $600 \mathrm{lbs} / \mathrm{cyd}$ \\
\hline Sand & $2515 \mathrm{lbs} / \mathrm{cyd}$ & $2515 \mathrm{lbs} / \mathrm{cyd}$ \\
\hline Water & 62 gals/cyd (Min) $/ 66$ gals/cyd (Max) & 62 gals/cyd (Min)/66 gals/cyd (Max) \\
\hline
\end{tabular}

Table 2

Flow Results For Mix 1 And Mix 2

\begin{tabular}{|c|c|c|}
\hline \multirow{2}{*}{$\begin{array}{c}\text { Water } \\
\text { (gal/cyd) }\end{array}$} & \multicolumn{2}{|c|}{ Flow (in) } \\
\hline & Mix 1 & $\operatorname{Mix} 2$ \\
\hline 62 (Min) & 10.80 & 9.75 \\
\hline 66 (Max) & 11.84 & 11.15 \\
\hline \multicolumn{3}{|c|}{ SRTC Laboratory Test } \\
\hline 66 (Max) & 11.00 & 9.75 \\
\hline
\end{tabular}

Table 3

Compressive Strength Results For Mix 1 And Mix 2

\begin{tabular}{|c|c|c|c|c|}
\hline Age & $\begin{array}{c}\text { Mix 1 Minimum } \\
\text { Water (psi) }\end{array}$ & $\begin{array}{c}\text { Mix 1 Maximum } \\
\text { Water (psi) }\end{array}$ & $\begin{array}{c}\text { Mix 2 Minimum } \\
\text { Water (psi) }\end{array}$ & $\begin{array}{c}\text { Mix 2 Maximum } \\
\text { Water (psi) }\end{array}$ \\
\hline \hline 7 Days & 95 & 105 & 75 & 20 \\
\hline 28 Days & 175 & 180 & 115 & 30 \\
\hline
\end{tabular}


Table 4

Mix 1 (150 lbs/cyd) - Bleed Water Volume And Percentage For Minimum And Maximum Water Content - 1 Foot Placement

\begin{tabular}{|c|c|c|c|c|}
\hline \multirow{2}{*}{ Elapsed Time } & \multicolumn{2}{|c|}{ Minimum Water $=62$ gals/cyd } & \multicolumn{2}{c|}{ Maximum Water =66 gals/cyd } \\
\cline { 2 - 5 } & Volume, $\mathrm{ml}$ & $\%$ Bleed Water & Volume, ml & $\%$ Bleed Water \\
\hline \hline 4 Hrs & 3300 & 13.78 & 4140 & 16.31 \\
\hline 1 Day & 2500 & 10.44 & 3390 & 13.36 \\
\hline 2 Days & 2340 & 9.77 & 3360 & 13.24 \\
\hline 3 Days & 2290 & 9.56 & 3080 & 12.14 \\
\hline 4 Days & 2280 & 9.52 & 3080 & 12.14 \\
\hline 5 Days & 2230 & 9.31 & 2990 & 11.78 \\
\hline 6 Days & 2200 & 9.18 & 2910 & 11.47 \\
\hline 7 Days & 1980 & 8.27 & 2840 & 11.19 \\
\hline
\end{tabular}

Table 5

Mix 1 (150 Ibs/cyd) - Bleed Water Volume And Percentage For Minimum And Maximum Water Content - 2 Foot Placement

\begin{tabular}{|c|c|c|c|c|}
\hline \multirow{2}{*}{ Elapsed Time } & \multicolumn{2}{|c|}{ Minimum Water $=62$ gals/cyd } & \multicolumn{2}{c|}{ Maximum Water =66 gals/cyd } \\
\cline { 2 - 5 } & Volume, mi & $\%$ Bleed Water & Volume, ml & $\%$ Bleed Water \\
\hline \hline 4 Hrs & 6500 & 13.57 & 8320 & 16.39 \\
\hline 1 Day & 4980 & 10.39 & 6190 & 12.20 \\
\hline 2 Days & 4530 & 9.45 & 5860 & 11.54 \\
\hline 3 Days & 4290 & 8.95 & 5750 & 11.33 \\
\hline 4 Days & 4160 & 8.68 & 5660 & 11.15 \\
\hline 5 Days & 4070 & 8.49 & 5600 & 11.03 \\
\hline 6 Days & 3720 & 7.76 & 5600 & 11.03 \\
\hline 7 Days & 3720 & 7.76 & 5600 & 11.03 \\
\hline
\end{tabular}




\section{Table 6}

Mix 1 (150 lbs/cyd) - Bleed Water Volume And Percentage For Minimum And Maximum Water Content - 3 Foot Placement

\begin{tabular}{|c|c|c|c|c|}
\hline \multirow{2}{*}{ Elapsed Time } & \multicolumn{2}{|c|}{ Minimum Water =62 gals/cyd } & \multicolumn{2}{c|}{ Maximum Water =66 gals/cyd } \\
\cline { 2 - 5 } & Volume, ml & $\%$ Bleed Water & Volume, ml & $\%$ Bleed Water \\
\hline \hline 4 Hrs & 8660 & 10.47 & 13415 & 15.31 \\
\hline 1 Day & 7310 & 8.84 & 11850 & 13.53 \\
\hline 2 Days & 7000 & 8.47 & 11640 & 13.29 \\
\hline 3 Days & 6650 & 8.04 & 11480 & 13.11 \\
\hline 4 Days & 6510 & 7.87 & 11450 & 13.07 \\
\hline 5 Days & 6460 & 7.81 & 11340 & 12.95 \\
\hline 6 Days & 6390 & 7.73 & 11290 & 12.89 \\
\hline 7 Days & 6225 & 7.53 & 11050 & 12.61 \\
\hline
\end{tabular}

Table 7

Mix 2 (50 lbs/cyd) - Bleed Water Volume And Percentage For Maximum Water Content - 3 Foot Placement

\begin{tabular}{|c|c|c|}
\hline & \multicolumn{2}{|c|}{ Maximum Water $=66$ gals $/$ cyd } \\
\hline Elapsed Time & Volume, $\mathrm{ml}$ & $\%$ Bleed Water \\
\hline \hline 4 Hrs & 13180 & 15.05 \\
\hline 1 Day & 12450 & 14.21 \\
\hline 2 Days & 12100 & 13.81 \\
\hline 3 Days & 11880 & 13.56 \\
\hline 4 Days & 11750 & 13.41 \\
\hline 5 Days & 11630 & 13.28 \\
\hline 6 Days & 11560 & 13.20 \\
\hline 7 Days & 11500 & 13.13 \\
\hline
\end{tabular}


Figure 1

Mix 1 (150 lbs.cyd) - Percentage Of Bleed Water Versus Elapsed Time For Minimum And Maximum Water Content 1 Foot Placement

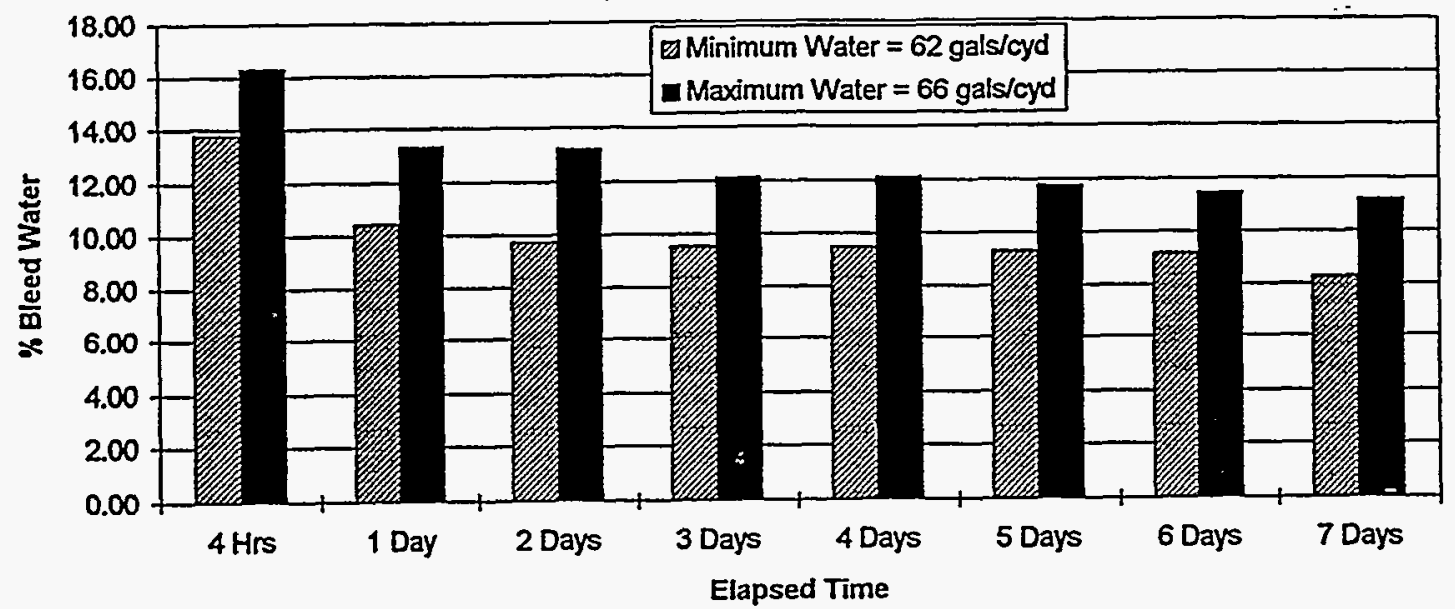

Figure 2

Mix 1 (150 lbs/cyd) - Percentage Of Bleed Water Versus Elapsed Time For Minimum And Maximum Water Content 2 Foot Placement

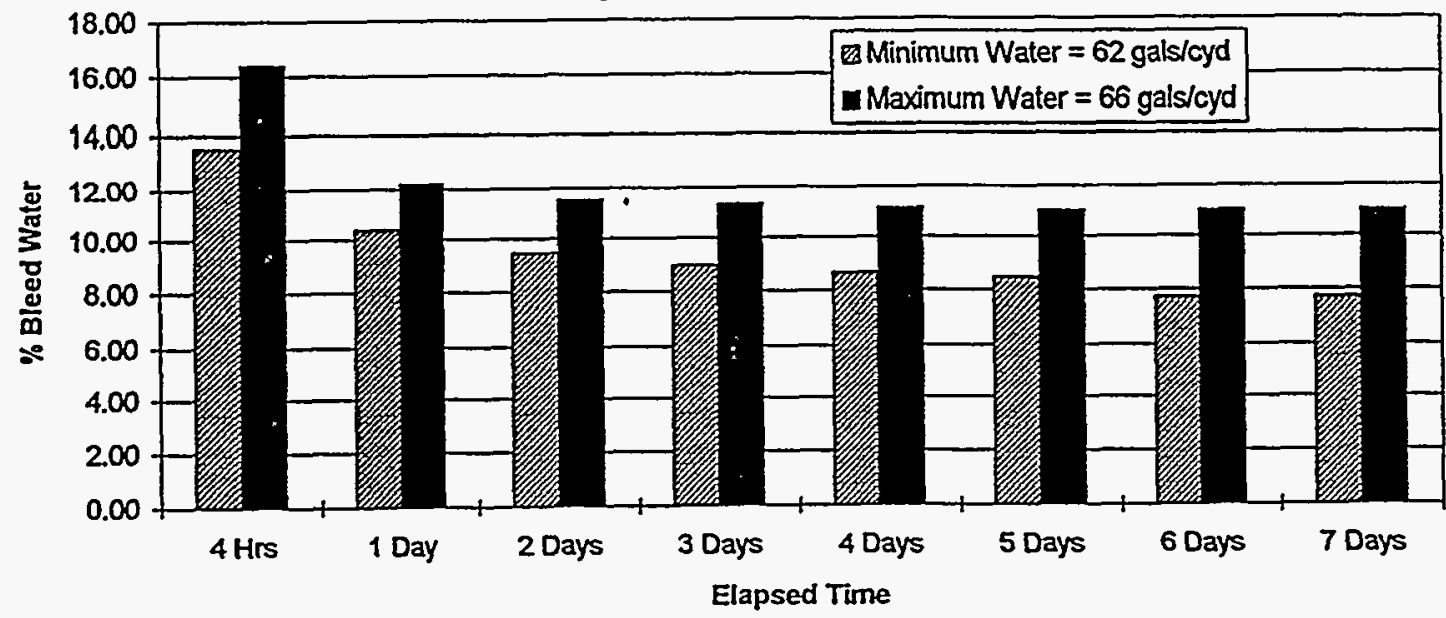


Figure 3

Mix 1 (150 lbs/cyd) - Percentage Of Bleed Water Versus Elapsed Time For Minimum And Maximum Water Content 3 Foot Placement

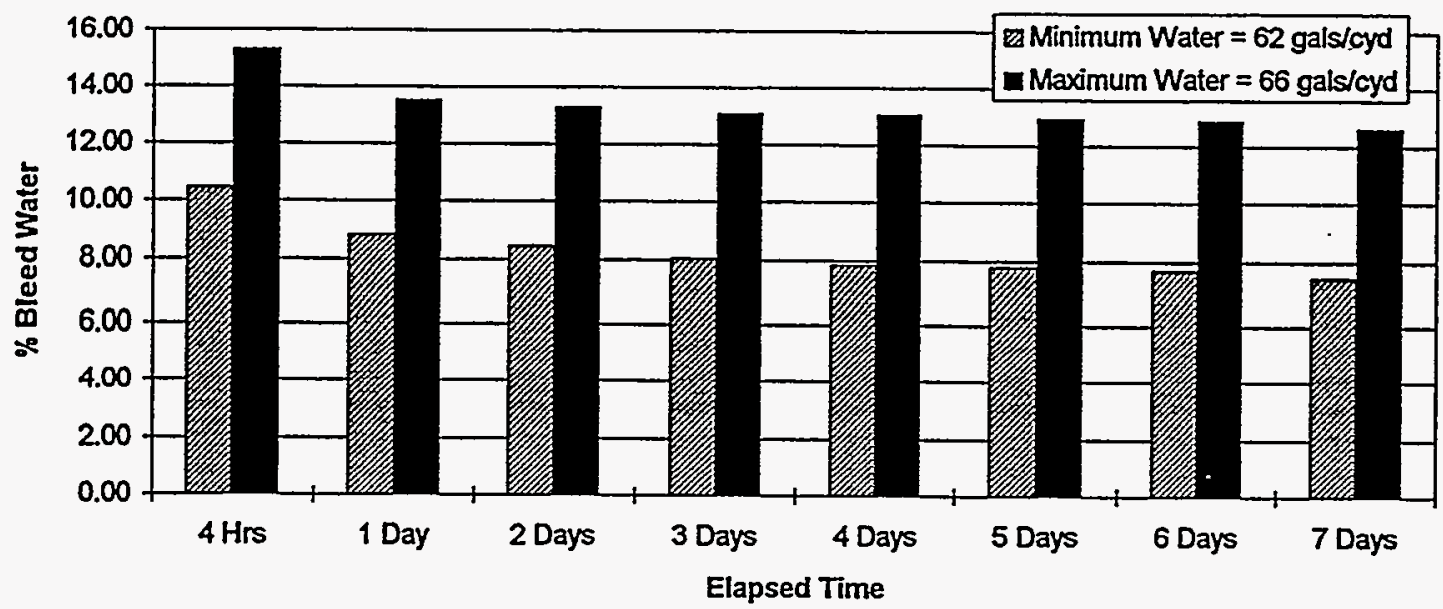

Figure 4

Mix 1 (150 lbs/cyd) - Minimum \& Maximum

1 Foot Placement

a 2 Foot Placement Water Comparison

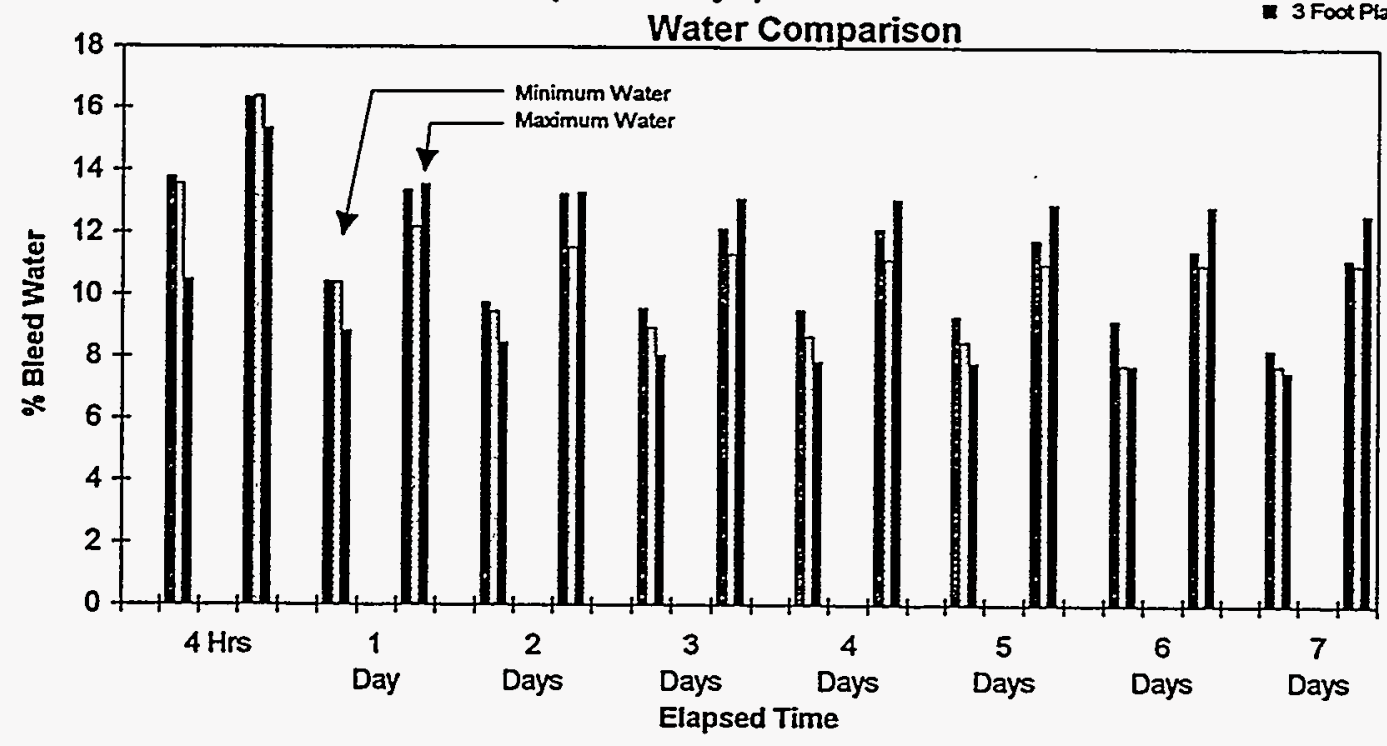


Figure 5

Mix 1 (150 lbs/cyd) - Percent Bleed Water Placement

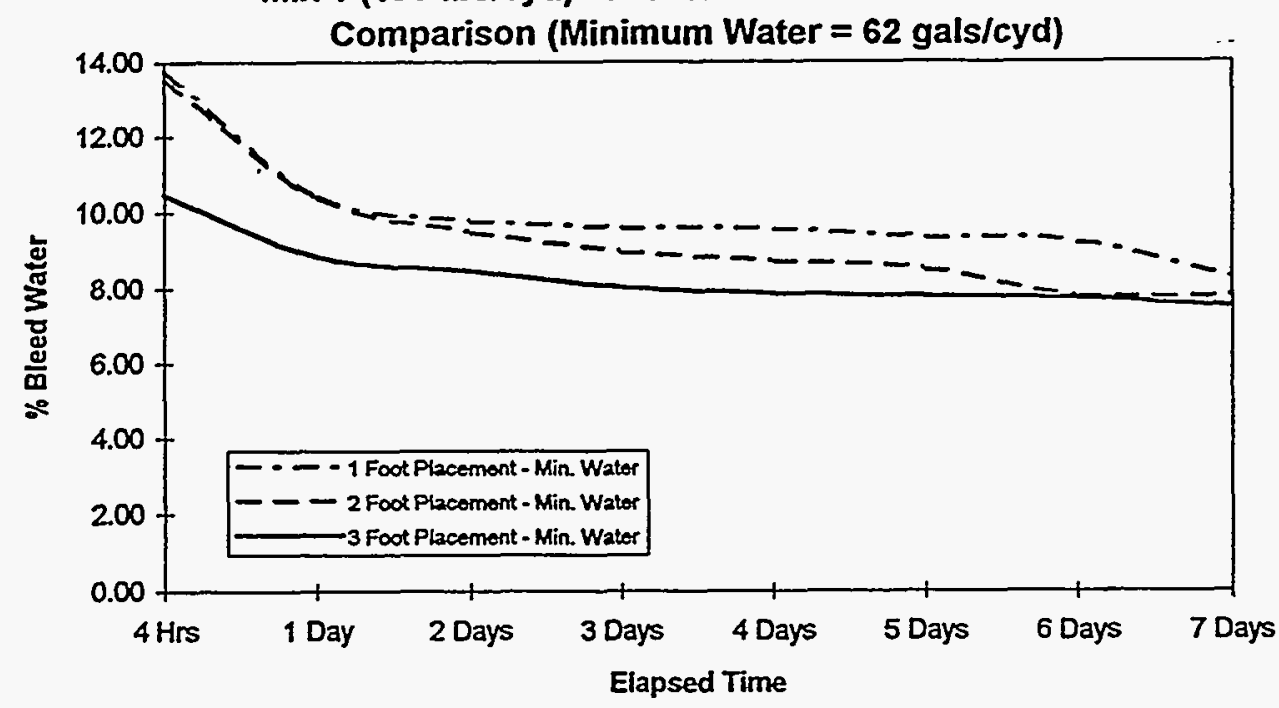

Figure 6

Mix 1 (150 lbs/cyd) - Percent Bleed Water Placement

Comparison (Maximum Water $=66$ gals/cyd)

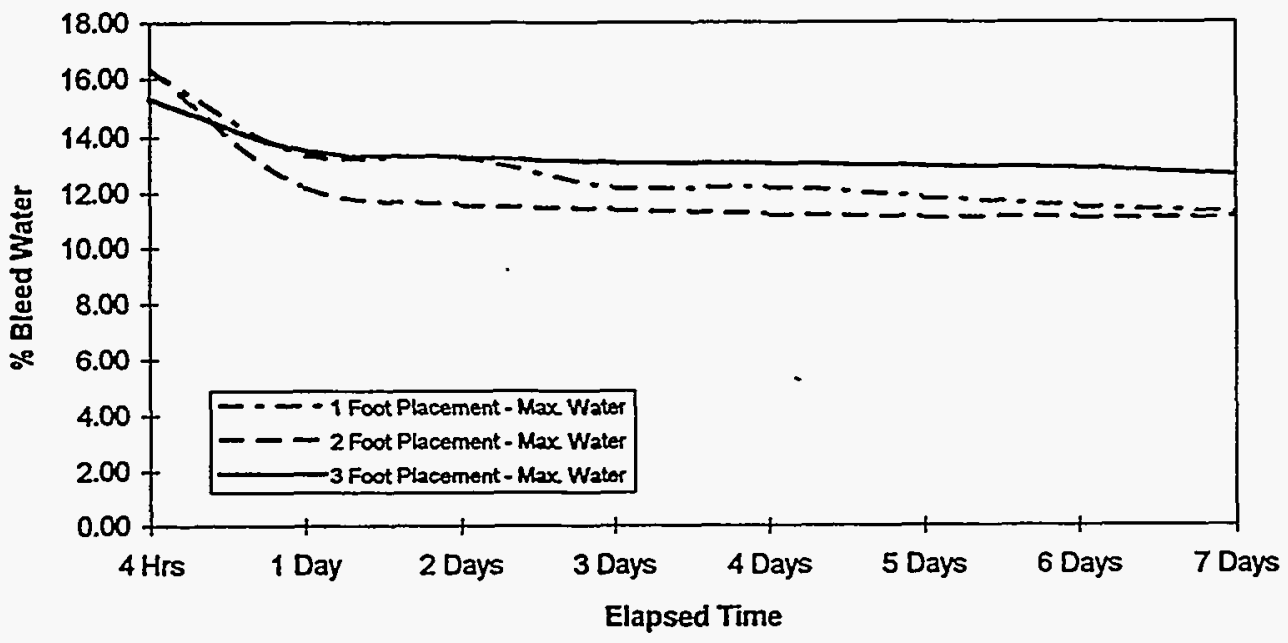


Figure 7

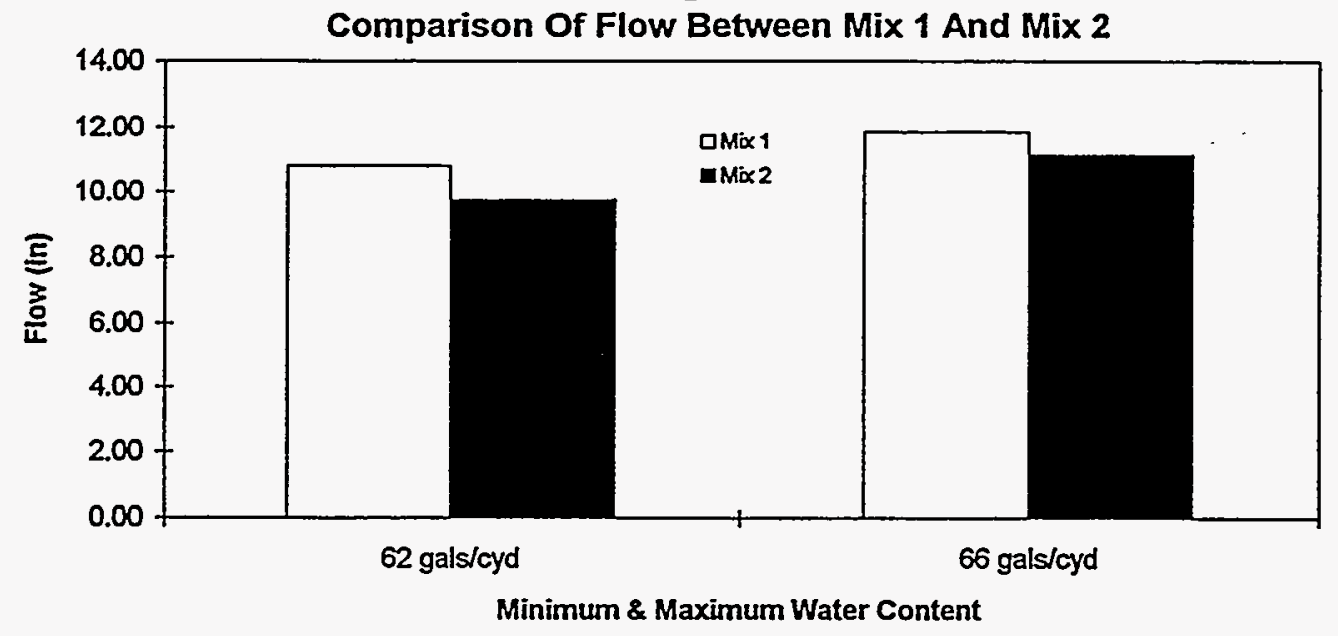

Figure 8

Mix 1 (150 lbs/cyd) - Compressive Strength Results For Minimum And Maximum Water Content

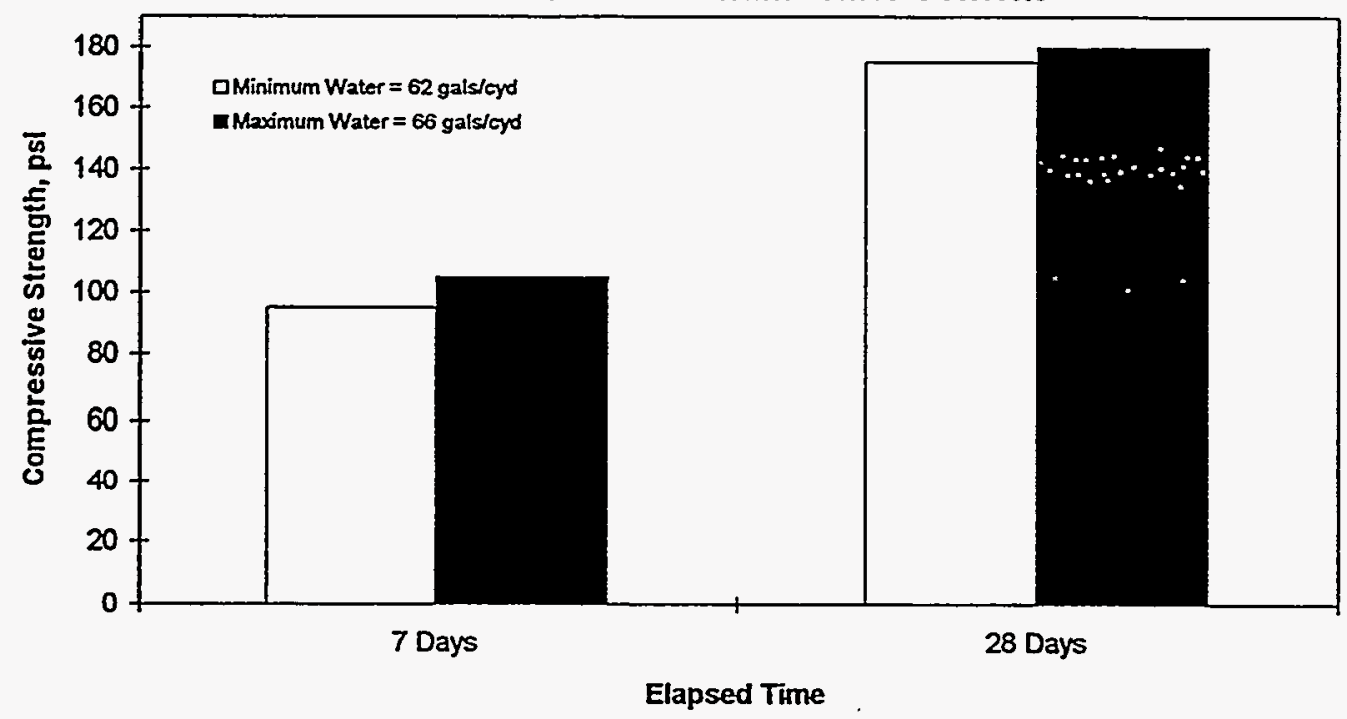


Figure 9

Mix 2 (50 lbs/cyd) - Compressive Strength Test Results For Minimum And Maximum Water Content

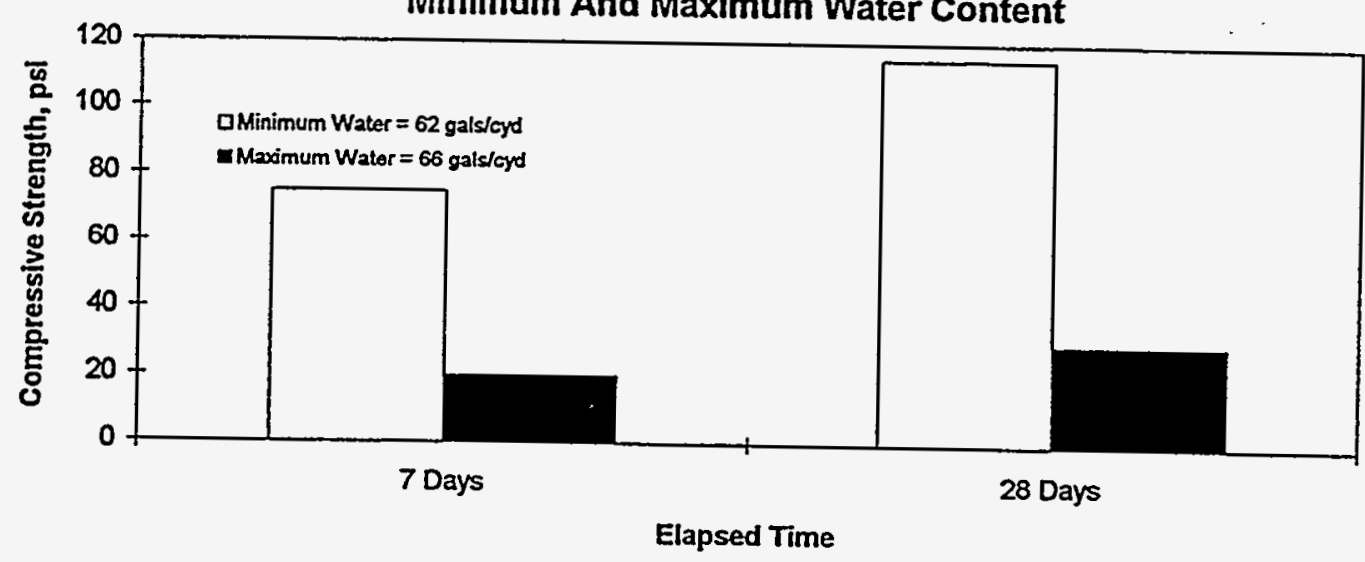

Figure 10

Percent Bleed Water Vs Mix 1

Water Content After 1, 2 And 3 Days

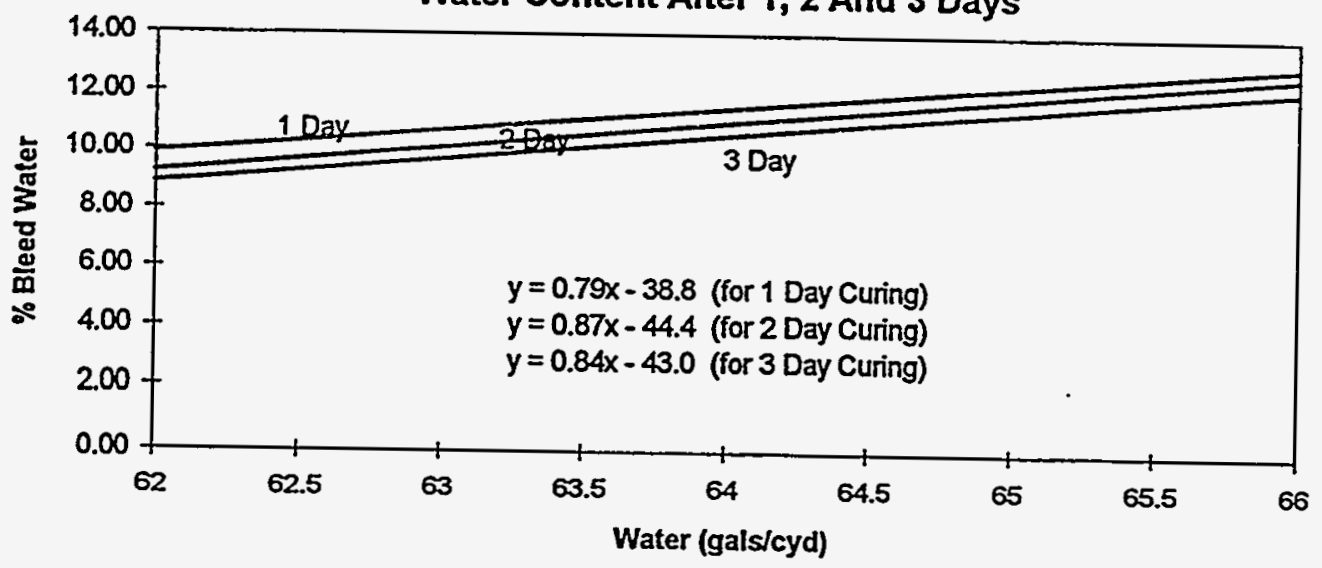


Figure 11

Flow Vs Water Content

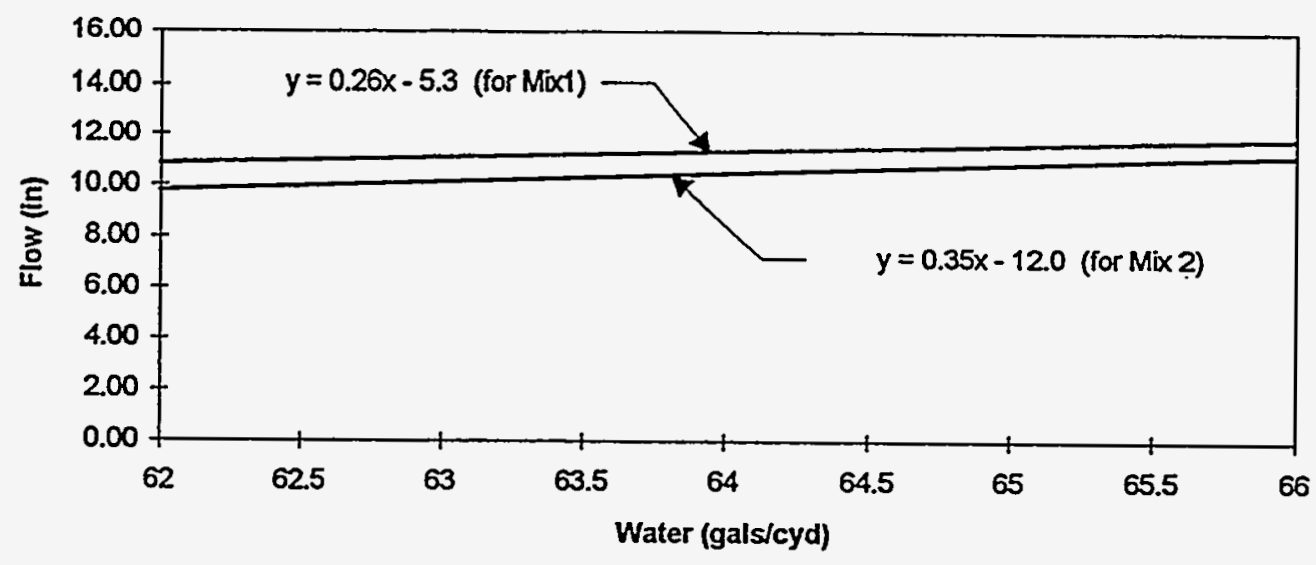




\section{OBJECTIVE:}

Measure the amount of bleed water for the below stated test CLSM mix design as a function of: pour height, cure time, and water content. Measure the compressive strength of the test samples. Measure the flowability of the test samples.

All work shall be charged to WAD No. WE114925, Activity Code No. W11492500.

\section{BLEED WATER TEST MATERIALS:}

1. 18 Containers With Lids

a) The containers are to be a minimum 2 feet diameter in width and the height shall be tall enough to accommodate 1, 2 and 3 foot depths of the material plus excess bleed water. They are to be made of steel or plastic. $\mathbf{5 5}$ gallon drums are an example of an acceptable container. It is important that lids are included with the containers.

2. CLSM Mix Design

a) The test CLSM mix design shall consist of the following:

i) Mix No. 1

$150 \# / c y d$ of cement, Type I/II

* one test for minimum (62 gal) and another for maximum (66 gal) of water content, $2515 \# / c y d$ of sand, 500 \#/cyd of fly ash,

ii) Mix No. 2

50 \#/cyd of cement, Type I/II

* one test for minimum (62 gal) and another for maximum (66 gal) of water content, $2515 \# /$ cyd of sand, $600 \# / c y d$ of fly ash, Type $F$

* The minimum water content as indicated here means optimum water needed to make it flowable. Therefore, the quantity may be adjusted.

b) The material can be obtained from an on site delivery, if available or may be batched.

c) Several batches (maximum 4) may be prepared provided that there is less than 15 minutes lapse time between batches. A single batch is preferred.

3. Miscellaneous Equipment

a) Tape, ruler, measuring jar, etc. for measuring the height of the initial CLSM placement and the height and volume of the bleed water. 


\section{BLEED WATER TEST PROCEDURE:}

1. Place the CLSM material (minimum water content) in a container to a height of about 1 foot.

2. Place the CLSM material (minimum water content) in a container to a height of about 2 feet.

3. Place the CLSM material (minimum water content) in a container to a height of about 3 feet

4. Place the CLSM material (maximum water content) in a container to a height of about 1 feet.

5. Place the CLSM material (maximum water content) in a container to a height of about 2 feet.

6. Place the CLSM material (maximum water content) in a container to a height of about 3 feet.

7. Measure the material height of each of the containers immediately after placement of the material into the containers.

8. Place lids on the containers immediately after the material has been placed and measured.

9. Remove the lids and measure the amount of bleed water 4 hours after the placement of the material.

a) Use a tape measure to determine the depth of the bleed water and calculate the volume, or

b) Siphon the bleed water into a container that can easily be used for determining the bleed water volume. Calculate the bleed water volume.

10. Replace lids back onto the containers.

11. Repeat steps 9 and 10 everyday for 7 days (skip weekends) for Mix Nos. 1 and 2.

12. If water is condensed on the underside of the container lids, drain it into the container to include for measurement. (Should be negligible.)

13. Record bleed water observations as follows:

Observation
Frequency
Initial Placement
4 Hours
Day 1
Day 2
Day 3
Day 4
Day 5
Day 6
Day 7
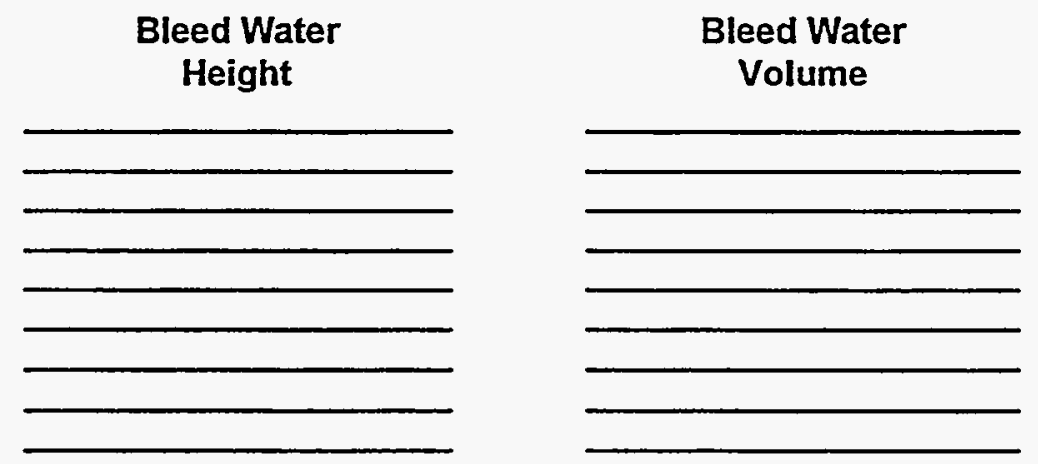

14. Record the following attributes during each bleed water observation:
a) consistency (flow cone test or modified flow test),
b) temperature,
c) settlement,
d) segregation. 


\section{COMPRESSIVE TEST MATERIALS AND PROCEDURE:}

1. Sample and test the above mix as typically done for compressive strength measurements.

2. The number of samples and frequency of tests shall be as follows:

\section{Testing Frequency \\ 7 Days \\ 28 Days}

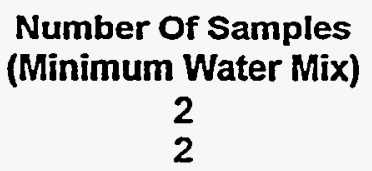

Number Of Samples
(Minimum Water Mix)

2

\author{
Number Of Samples \\ (Maximum Water Mix) \\ 2 \\ 2
}

\section{FLOW CONE TEST METHOD OR MODIFIED FLOW TEST AND PROCEDURE:}

1. Perform the flow cone test in accordance with ASTM C939.

2. Perform the following flow test (proposed $\mathrm{ACl} 229$ ):

The procedure consists of placing a 3 inch by 6 inch long open ended cylinder vertically on a level surface and filling the cylinder to the top with the mix designs. The cylinder is then lifted vertically to allow the material to flow out onto the level surface. Good flowability is achieved when there is no noticeable segregation and the material spread is at least 8 inches in diameter.

Record the diameter of the resultant flow spread at 2 separate locations which are about $180^{\circ}$ apart from each other. Calculate the average of the diameters. 